\title{
土運船による土砂投入時の堆積形状 に関する水理模型実験 \\ THE HYDRAULIC MODEL EXPERIMENT OF SEDIMENT DISCHARGING SOIL FOR DUMPING HOPPER BARGE WITH BOTTOM DOORS
}

\author{
西山泰弘 1 ・稲葉徹 $2 \cdot$ 折橋恒春 $3 \cdot$ 法橋一賢 4 \\ Yasuhiro NISHIYAMA, Toru INABA, Tsuneharu ORIHASHI and Kazuyoshi HOKKYO \\ 1 正会員 五洋建設株式会社大阪支店（干530-0001 大阪市北区梅田2-5-25八-ビ XOSAKA） \\ 2正会員 五洋建設株式会社大阪支店（テ530-0001 大阪市北区梅田2-5-25ハ-ビ X0SAKA）

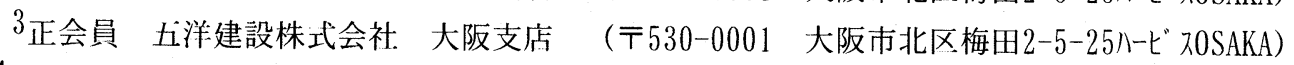 \\ 4日本海洋コンサルタント株式会社：技術開発第二部（广102-0082 東京都下-代田区 -番町27-4）
}

\begin{abstract}
Rapid construction according [ mound construction of the shore protection in the Kansai International Airport second construction ] to a lot of sand injection using larger dumping hopper barge carried out. if sand are thrown in locally, formation of steep deposition form will be caused, and we are anxious about the intensity of the foundations improved by slide destruction falling.

It turns out that it is important for the stability of foundations as for predicting the form after sand injection in advance, and finishing uniformly over a reclamation zone at large by it from this. Then, this research performed deposition form of sand thrown in on foundations for the purpose of development of the technique predicted with sufficient accuracy.
\end{abstract}

Key Words : Kansai International Airport, sediment discharging soil, dumping hopper barge

\section{1. 研究の目的}

関西国際空港 2 期工事における護岸のマウンド築 造は, 大型土運船を用いて大量の土砂投入による急 速施工が実施されている。マウンド築造工事におい て，土砂を局所的に投入すると急峻な堆積形状の形 成を招き，すべり破壊によって改良した地盤の強度 が低下することが懸念される.

このことから，土運船で土砂投入後の形状を事前 に予測し，埋め立、て区域全般にわたって均・に仕上 げることは，地盤の安定性にとって重要であること がわかる.

そこで, 本研究は, 地盤上に投入した土砂の堆積 形状を精度良く予測する基礎的な手法の開発を目的 として行った。

\section{2. 堆積形状予測手法}

現在, 土砂投入後の堆積形状を予测する手法とし て様々なモデルが提案されている，厳密なモデルと して土砂拡散シミュレーションを用いた堆積形状予 测手法があるが，計算時間がかかること，境界条件 などを設定する必要があることなどから，何千投も する大型マウンド造成等の実務への適用性は難しい. そのため, これまでに行われているものとしては,
簡易的な予測手法が主に使用されている.

使用実績のある簡易堆積形状予測モデルの代表的 なものとしては，2次元モデルである三菱モデル" や，仮想 3 次元モデルである造成 I 工区モデル2) 等 が挙げられる。

土運船から投下した土砂は土砂量, 水深の大小, 土運船の浮上状況との兼ね合いでそれぞれ異なる速 度で海底面に衝突し, その後, 側方へと流動する。 流動規模は, 海底面への衝突速度, 流体抵抗, 底面 摩擦などの他に以下に示すような様々なパラメータ が考えられる。

・土運船土倉の形状

- 積載土量

·土砂特性（粘性，粒度，単位体積重量等）

・投下水深

・土運船扉の開閉速度

- 海底形状

・海底土質（砂，年度，改良地盤等）

しかし，簡易モデルで算定する堆積厚は，単体の 堆積形状算定結果を単純に重ね合わせしたものであ るため, 土砂投入時の衝撃纴で投入前海底面が締固 められたり, 堆積していた土砂が崩れたりするよう な, 実際に生じている現象が反映されていない. 
そのため，これらの簡易モデルで算出した堆積厚 は，2 割程度高めの値となっている（武藤ら， 1974).

本研究では，上記したような各種パラメータに対 して 3 次元の水理模型実験を実施し, 堆積形状の基 礎デー夕を計測することによって 3 次元の堆積形状 データベースを構築することとした。

任意水深及び，土量に対する形状は，堆積形状 データベースの值を線形補間して求めることにより. 現地へ適用することが可能である.

本研究における堆積形状の予測手法を図一 1 に示 す.

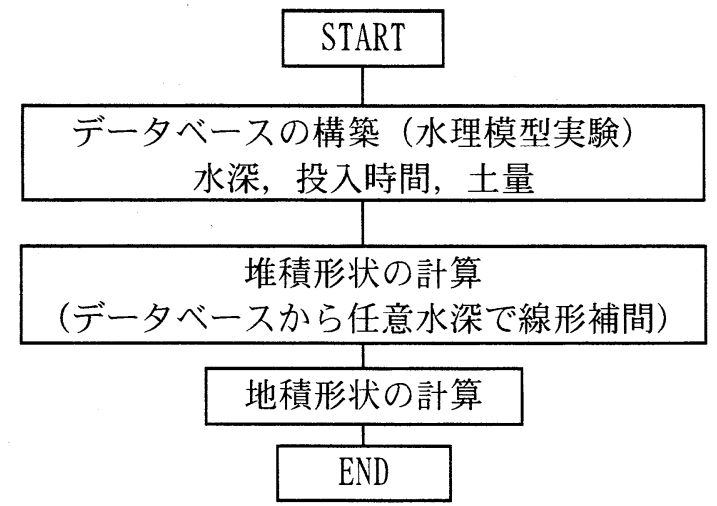

図一 1 堆積形状予測手法フロー

\section{3. 実験内容}

(1) 実験施設

水理模型実験は，図一 2 に示すアクリル製の観測 空（正面 $2 \mathrm{~m}$, 側面側 $1 \mathrm{~m}$ ） を有する長さ $4.0 \mathrm{~m} \times$ 幅 2.0 $\mathrm{m} \times$ 深さ0.9mの水槽を用いて行った.
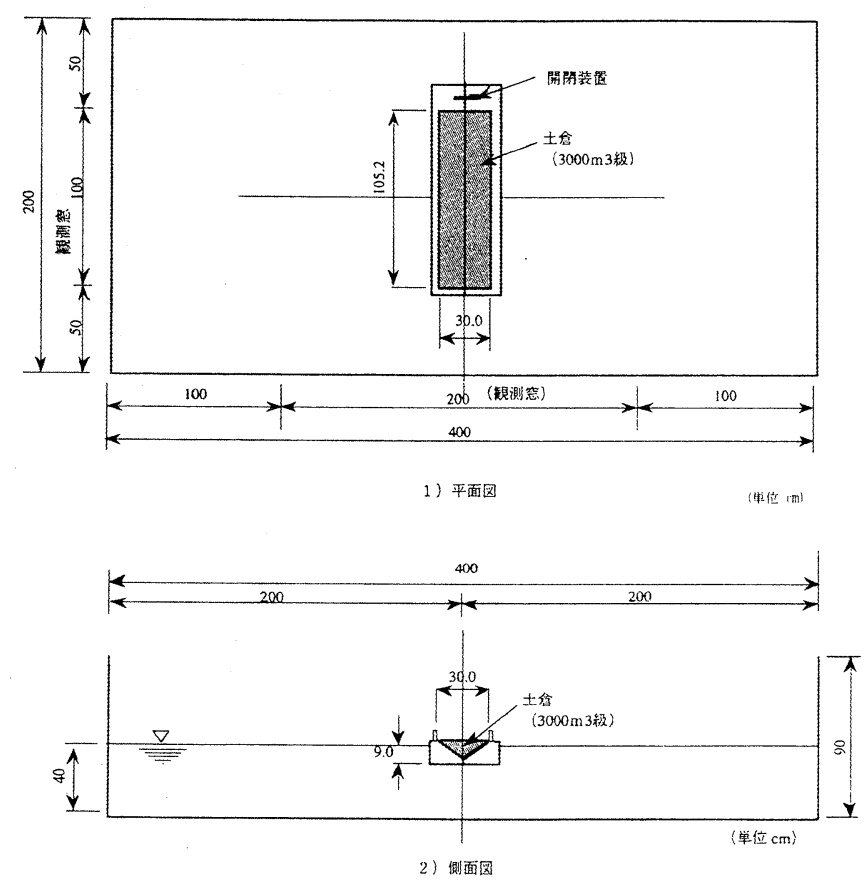

図一 2 実験水層諸元

\section{（2）実験縮尺}

実験に使用した土運船の模型縮尺は, 現地規模と 実験装置を勘案して，3,000 $\mathrm{m}^{3}$ 級全開式土運船では $1 / 50,6,000 \mathrm{~m}^{3}$ 級全開式土運船で $1 / 67$, 底開式土運 船で1/100とした。

\section{（3）実験土層}

水理模型実験で用いる海底地形としては，関西国 際空港 2 期工事における現地の軟弱層を想定して, 含水比 $50 \%$ に調節したカオリン粘土とその上に敷き 砂（6 号珪砂）を敷設したものを使用した.

実験土層を図一 3 に示す。

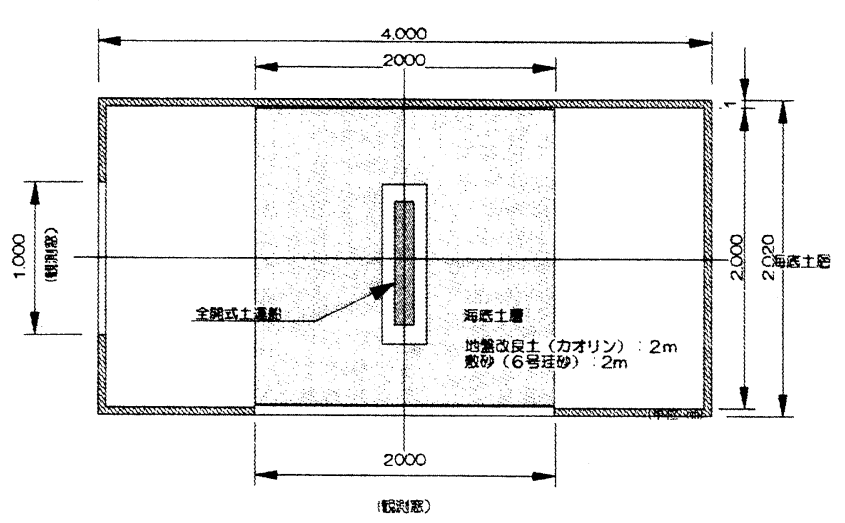

平面図

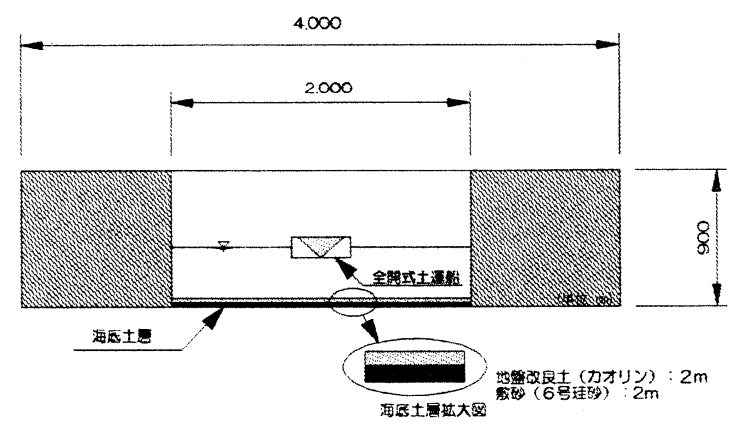

正面図

\section{(4) 実験機器}

\section{図一 3 実験土層}

土砂投入後の堆積形状の测定は，水槽上部に 3 次 元の超音波式砂面計（自動 x y トラバース）を設置 して5cmピッチで測定を行った.

\section{4. 実験ケース}

実験ケースは，投入水深 $(7.0 \mathrm{~m}, 10.0 \mathrm{~m}, 15.0 \mathrm{~m}$, $20.0 \mathrm{~m})$ ，士量 $\left(500 \mathrm{~m}^{3}, 1,000 \mathrm{~m}^{3}, 3,000 \mathrm{~m}^{3}\right.$ ， $\left.6,000 \mathrm{~m}^{3}\right)$ ，開閉速度 $(70 \mathrm{sec}, 140 \mathrm{sec}, 210 \mathrm{sec})$ を 変化させて行った。

また，現地への適用性を考慮し，単体の堆積形状 のみでなく，土運船の投入間隔（図一 4 参照）を変 化させた場合の堆積形状の重ね合わせについても実 験を行った。

本研究で行った水理模型実験ケースの一覧を表一 1 に示す. 
表一 1 水理模型実験ヶース

\begin{tabular}{|c|c|c|c|c|c|c|}
\hline ケース & $\begin{array}{c}\text { バ } \\
! \\
シ ゙ \\
\end{array}$ & $\begin{array}{c}\text { 土量 } \\
\left(\mathrm{m}^{3}\right)\end{array}$ & $\begin{array}{l}\text { 開閉 } \\
\text { 時間 } \\
\text { (sec) } \\
\end{array}$ & $\begin{array}{c}\text { 投下 } \\
\text { 水深 } \\
\text { (m) }\end{array}$ & \begin{tabular}{|c} 
投下 \\
間隔 \\
$(\mathrm{m})$ \\
\end{tabular} & $\begin{array}{l}\text { 模型 } \\
\text { 縮尺 }\end{array}$ \\
\hline Case-1 & \multirow{8}{*}{$\begin{array}{l}\text { 底 } \\
\text { 開 } \\
\text { 式 }\end{array}$} & \multirow{4}{*}{500} & \multirow{8}{*}{-} & 7.0 & - & \multirow{8}{*}{$1 / 100$} \\
\hline Case-2 & & & & 10.0 & - & \\
\hline Case-3 & & & & 15.0 & - & \\
\hline Case -4 & & & & 20.0 & - & \\
\hline Case-5 & & \multirow{4}{*}{1,000} & & 7.0 & - & \\
\hline Case-6 & & & & 10.0 & - & \\
\hline Case-7 & & & & 15.0 & - & \\
\hline Case-8 & & & & 20.0 & - & \\
\hline Case-9 & \multirow{33}{*}{ 全 } & \multirow{21}{*}{3,000} & \multirow{4}{*}{70} & 7.0 & - & \multirow{21}{*}{$1 / 50$} \\
\hline Case-10 & & & & 10.0 & - & \\
\hline Case-11 & & & & 15.0 & - & \\
\hline Case-12 & & & & 20.0 & - & \\
\hline Case-13 & & & \multirow{13}{*}{140} & 7.0 & - & \\
\hline Case-14 & & & & \multirow{4}{*}{10.0} & - & \\
\hline Case-15 & & & & & 0 & \\
\hline Case-16 & & & & & 15 & \\
\hline Case-17 & & & & & 30 & \\
\hline Case-18 & & & & \multirow{4}{*}{15.0} & - & \\
\hline Case-19 & & & & & 0 & \\
\hline Case-20 & & & & & 15 & \\
\hline Case-21 & & & & & 30 & \\
\hline Case-22 & & & & \multirow{4}{*}{20.0} & - & \\
\hline Case-23 & & & & & 0 & \\
\hline Case-24 & & & & & 15 & \\
\hline Case-25 & & & & & 30 & \\
\hline Case-26 & & & \multirow{4}{*}{210} & 7.0 & - & \\
\hline Case-27 & & & & 10.0 & - & \\
\hline Case-28 & & & & 15.0 & - & \\
\hline Case-29 & & & & 20.0 & - & \\
\hline Case-30 & & \multirow{12}{*}{6,000} & \multirow{4}{*}{70} & 7.0 & - & \multirow{12}{*}{$1 / 67$} \\
\hline Case-31 & & & & 10.0 & - & \\
\hline Case-32 & & & & 15.0 & - & \\
\hline Case-33 & & & & 20.0 & - & \\
\hline Case- -34 & & & \multirow{8}{*}{210} & 7.0 & - & \\
\hline Case-35 & & & & 10.0 & - & \\
\hline Case-36 & & & & 15.0 & - & \\
\hline Case-37 & & & & 20.0 & - & \\
\hline Case-38 & & & & 7.0 & - & \\
\hline Case-39 & & & & 10.0 & - & \\
\hline Case -40 & & & & 15.0 & - & \\
\hline Case-41 & & & & 20.0 & - & \\
\hline
\end{tabular}

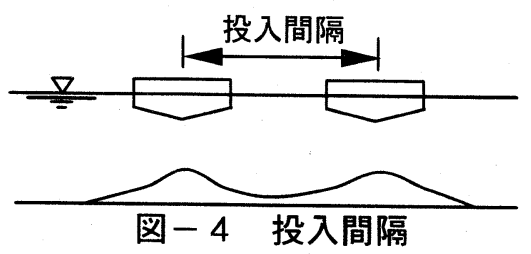

\section{5. 研究結果}

\section{(1) 投入水深の特性}

実験から投入水深が深くなると二山型に堆積する ことが分かった. 図一 5 (1)〜 (4) に土砂堆積形状の 実験值と 2 次元モデルの比較結果を示す. 図には 2 次元モデルである三菱モデルと造成 I 工区モデルに よる計算値も示した.

実験の堆積形状は, 水深が $7 \mathrm{~m}$ と $10 \mathrm{~m}$ のときは三 菱モデルと一致し，水深が $15 \mathrm{~m}$ と $20 \mathrm{~m}$ のケースでは 造成 I 工区モデルに近い形状となる。水深 $7 \mathrm{~m}, 10$ $\mathrm{m}, 15 \mathrm{~m}, 20 \mathrm{~m}$ の実験值を用い $12 \mathrm{~m}$ の堆積形状を予 測した計算結果の一例を図一6に示す。
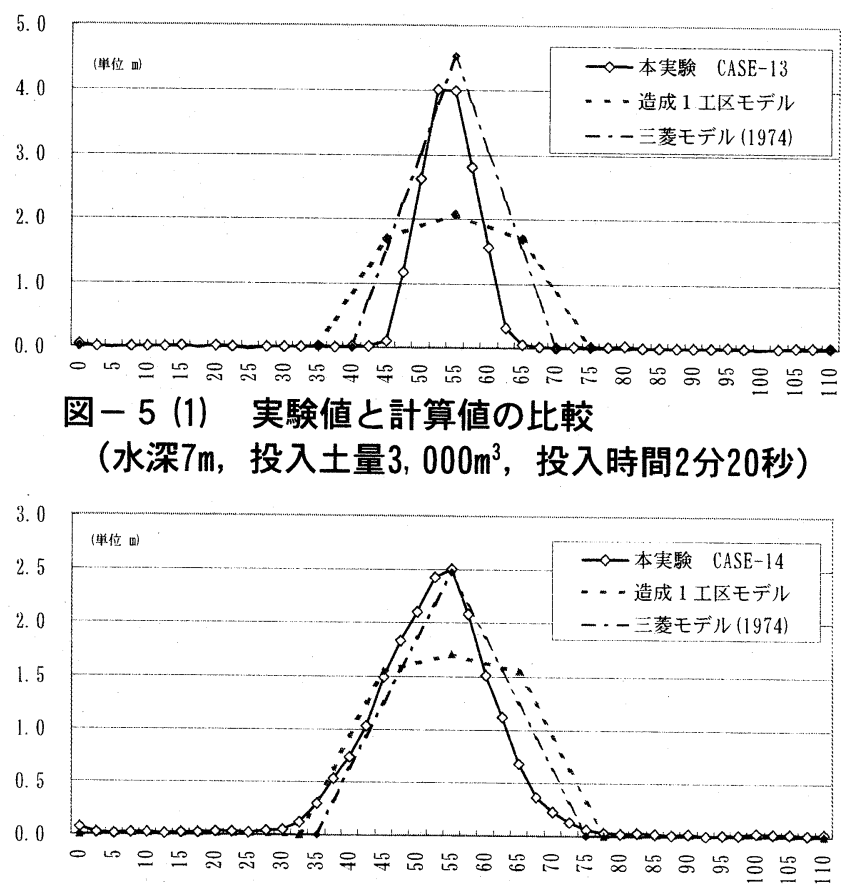

図- 5 (2) 実験值と計算値の比較

(水深 $10 \mathrm{~m}$, 投入土量 $3,000 \mathrm{~m}^{3}$, 投入時間2分20秒)

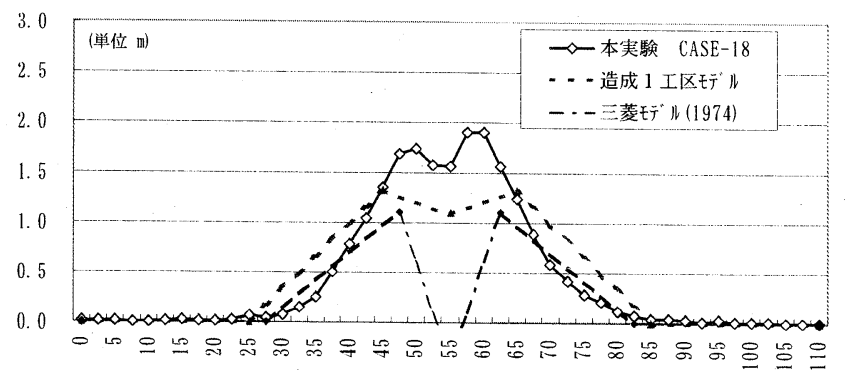

図-5 (3) 実験值と計算値の比較

（水深 $15 \mathrm{~m}$ ，投入土量 $3,000 \mathrm{~m}^{3}$ ，投入時間2分20秒）

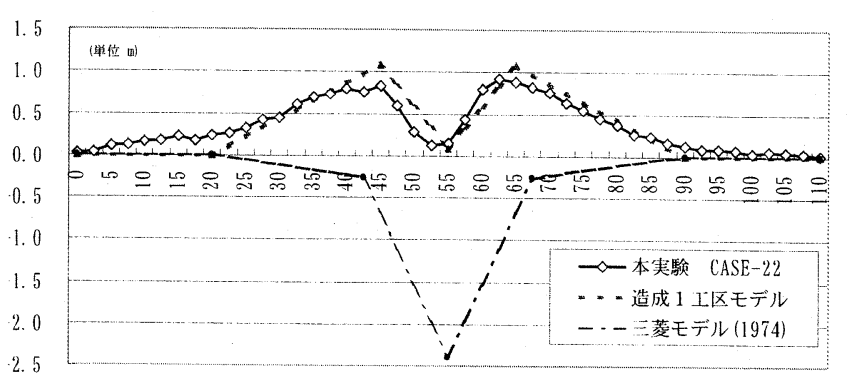

図- 5 (4) 実験值之計算値の比較

（水深 $20 \mathrm{~m} ，$ 投入土量 $3,000 \mathrm{~m}^{3}$ ，投入時間2分20秒） 

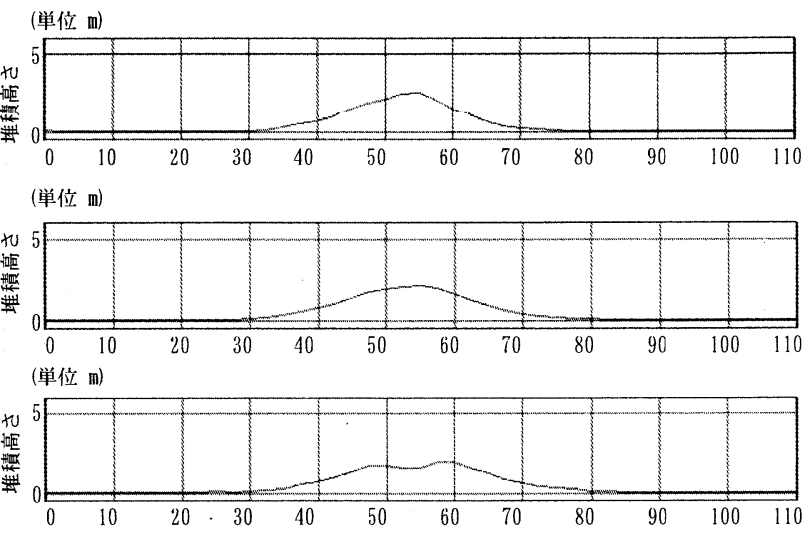

図一 6 堆積形状予測結果（水深12m）

\section{(2) 開閉時間の特性}

開閉時間 $70 \mathrm{sec} ， 140 \mathrm{sec} ， 210 \mathrm{sec} の$ 違いに対する 堆積形状特性は，いずれの水深においても開閉時間 が早い場合には，中央の高さは低く両サイドに広が る傾向にあることが分かった，逆に開閉時間が遅く なると中央部に高く堆積する傾向を示した.

実験結果を図一7 (1)〜 (3) に示す.

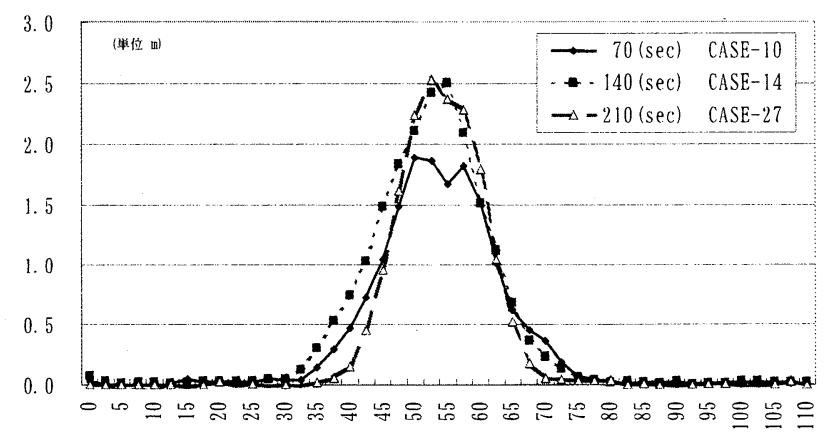

図－7（1）投入時間による堆積形状（水深10m）

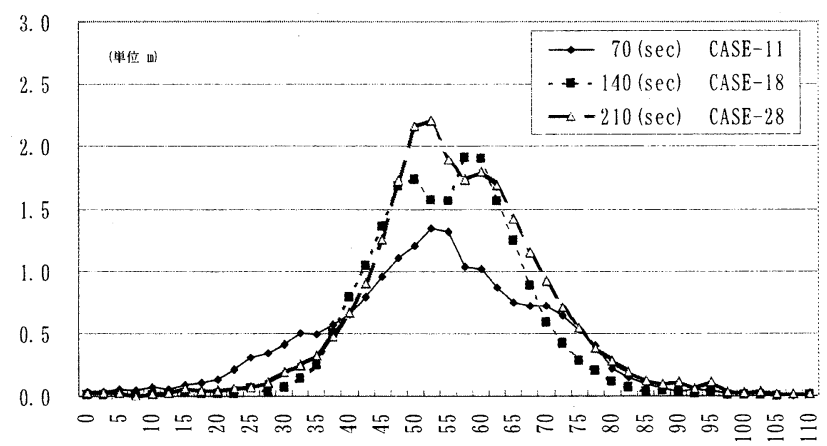

図－7 (2) 投入時間による堆積形状（水深 $15 \mathrm{~m}$ )

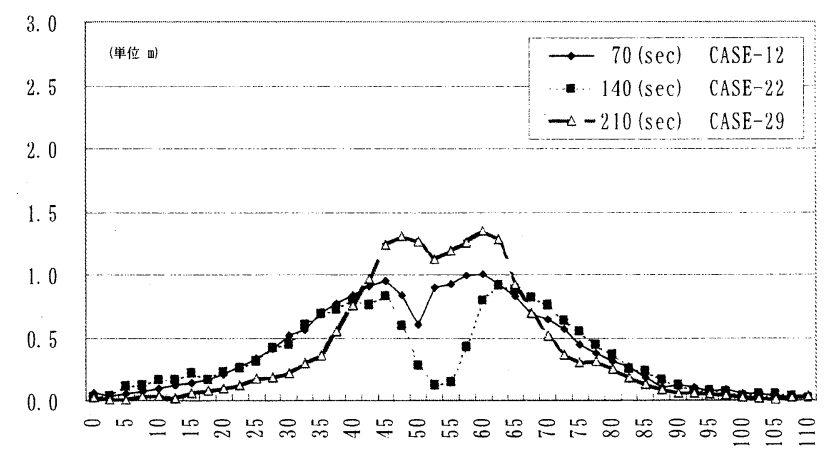

図－7（3）投入時間による堆積形状（水深 $20 \mathrm{~m}$ ）

\section{（3）投入土容量の特性}

投入土量容量が $3,000 \mathrm{~m}^{3}, 6,000 \mathrm{~m}^{3}$ の場合の堆積形 状は，いずれの水深においても堆積する範囲は，ほ ぼ同じであるが，投入土量によって堆積高さが変化 することが分かった.

実験結果を図ー8 (1)〜 (3) に示す.
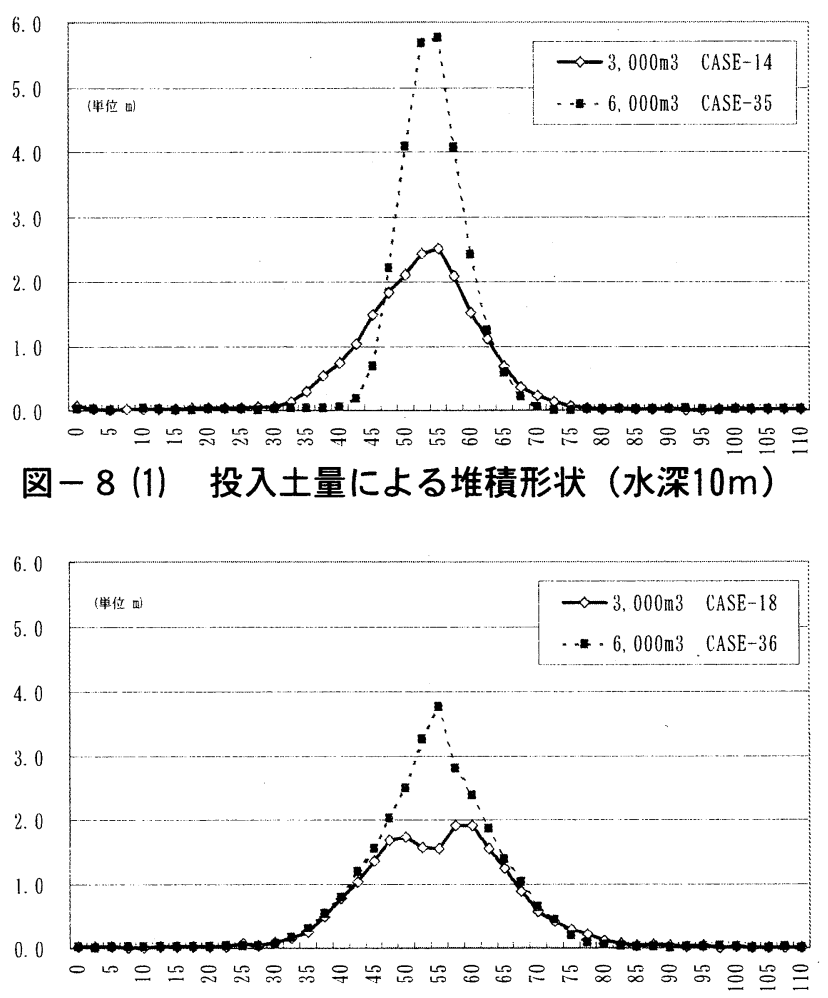

図一8（2）投入土量による堆積形状（水深15m)

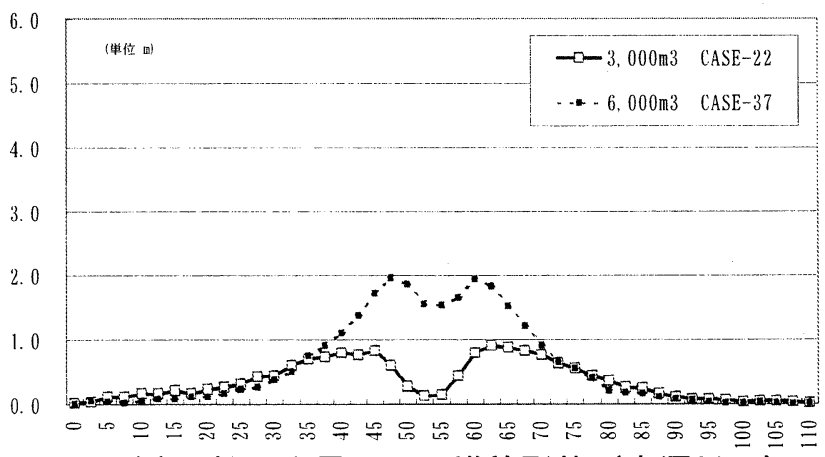

図－8（3）投入土量による堆積形状（水深20m）

\section{（4）堆皟形状データベースの構筑}

表一 1 に示した水理模型実験結果を基に, 土量, 開閉時間，投下水深をパラメータとした 3 次元の堆 積形状データベースを構築した.

この堆積形状データベースを線形補間して用いる ことで，土量 $500 \mathrm{~m}^{3} \sim 6,000 \mathrm{~m}^{3}$, 開閉時間 $70 \mathrm{sec} \sim$ $210 \mathrm{sec}$ ，投下水深 $7.0 \mathrm{~m} \sim 20.0 \mathrm{~m}$ までの範囲であれば 任意の条件下での 3 次元堆積形状を予測することが 可能である.

また，このデータベースは実験値を基に構築して おり，水深が7. $0 \mathrm{~m}, 10.0 \mathrm{~m}$ では前述した三菱モデル 
の堆積形状とほぼ・致し，水深が $15.0 \mathrm{~m}, 20.0 \mathrm{~m}$ は造成 I 工区モデルと同様な堆積形状となることが 本計算手法の特徵として挙げられる。

\section{(5) 堆積形状の重ね合わせ}

図一9 (1) 〜 (4) は, 単体の実験值 (Case-19: 土 量 $3,000 \mathrm{~m}^{3}$, 開閉時間 $140 \mathrm{sec}$ ，投下水深 $15.0 \mathrm{~m} ）$ と堆 積形状データベースを用いて計算した値を重ねて表 示したものである.

図一 10 (1)〜 (4) 及び, 図-1 1 (1)〜 (4) は,

1 投目と 2 投目の間隔を $15 \mathrm{~m} 及 ひ ゙ ， 30 \mathrm{~m}$ 間隔を開け て土砂を投下した場合の実験値と計算値を重ねて表 示したものである。このときの計算值は，堆積形状 データベースを用いて 1 投目，2 投目をそれぞれ計 算し，それらの堆積形状計算値を鉛直方向に積分

（重ね合わせ）することで 1 投目， 2 投目を重站合 わせた堆積形状を算定したものである.

図一 10 及び，図一 11 で計算値と実験值を比較 した結果, 図中の右肩部分で計算値が実験値よりも 小さくなる傾向が見られた。これは、1 投目の堆積 土砂の法面に 2 投目の土砂を投入したことで落下に 伴う流況が変化したことなどが影響しているためと 考えられる.

このように，図中の右肩部分では若干ずれるもの の, 堆積高のピーク值付近での計算值は, 実験值を ほぼ再現しているものと考えられる。

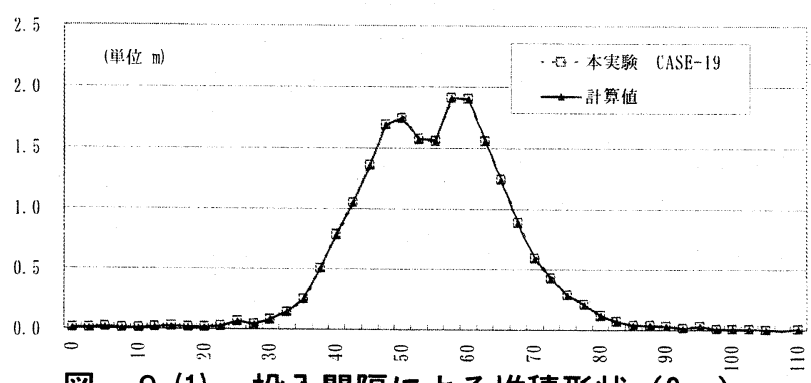

図ー9 (1) 投入間隔による堆積形状 $(0 \mathrm{~m})$

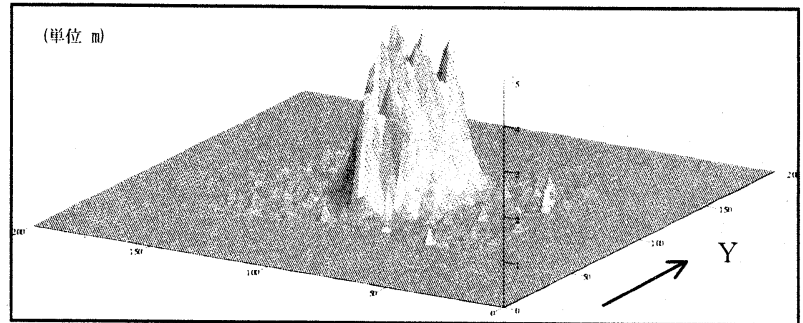

図-9 (2) 鳥瞰図（投入間隔: $0 \mathrm{~m}$ )

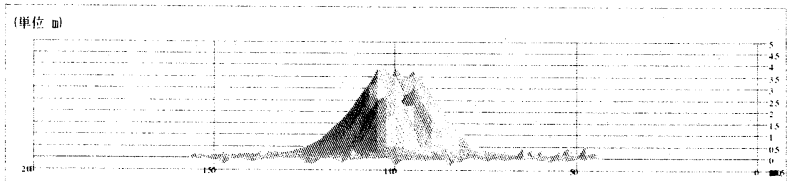

図 -9 (3) X方向見通図（投入間隔：0m）

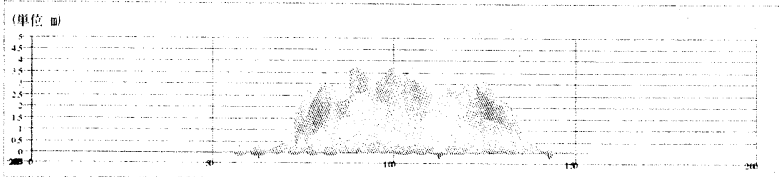

図-9(4) $Y$ 方向見通図（投入間隔 : $0 m$ ）

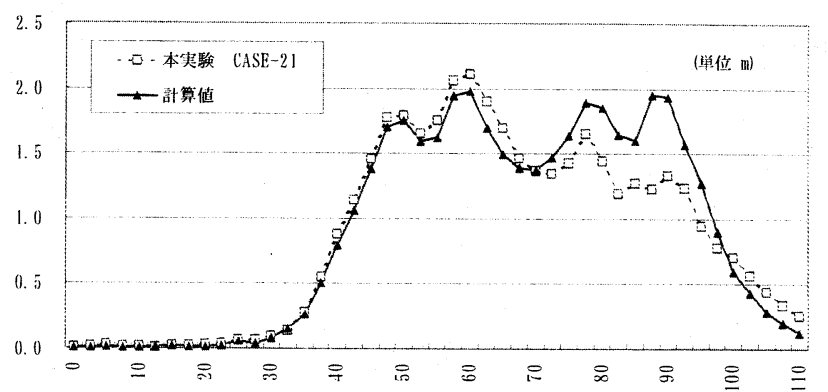

図－10（1）投入間隔による堆積形状 $(15 \mathrm{~m})$

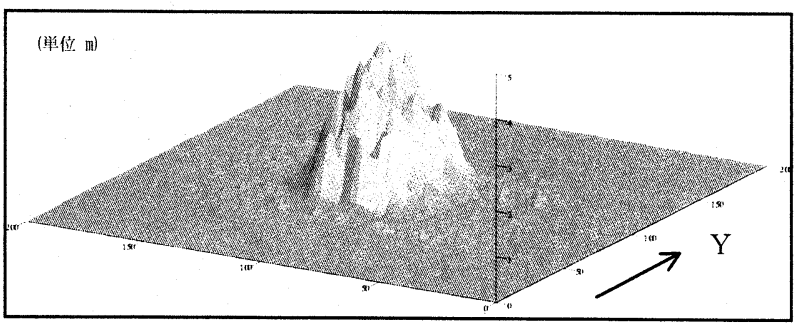

図-10 (2) 鳥瞰図（投入間隔: $15 \mathrm{~m}$ )

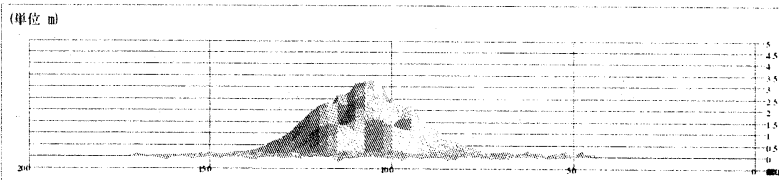

図-10(3) X方向見通図（投入間隔: $15 \mathrm{~m}$ )

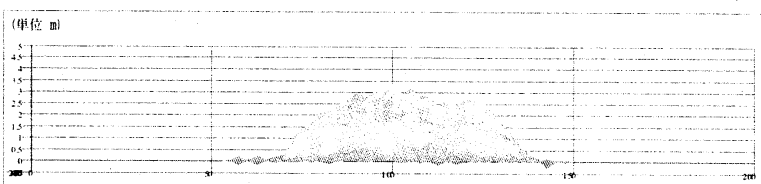

図-10（4） Y方向見通図（投入間隔：15m）

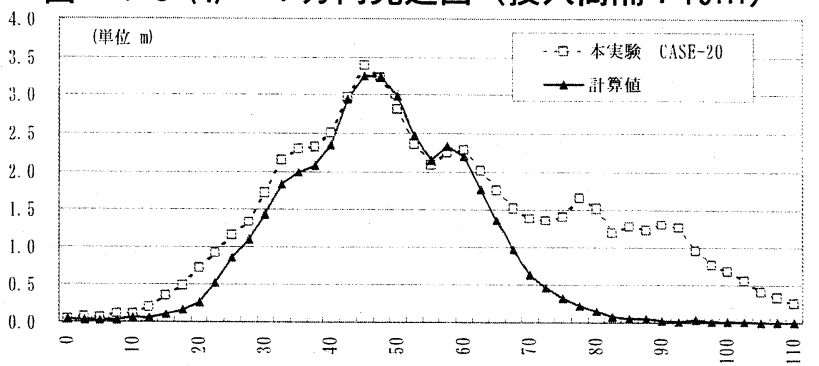

図－1 1 (1) 投入間隔による堆積形状 $(30 \mathrm{~m})$

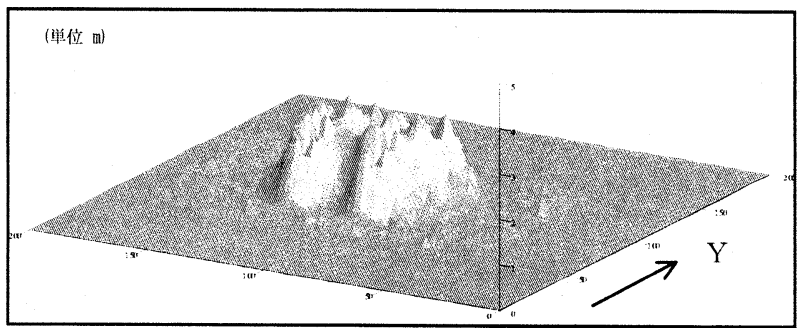

図-11（2）鳥瞰図（投入間隔: $30 \mathrm{~m}$ )

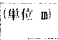

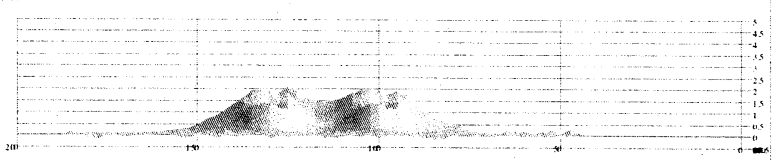

図-1 1 (3) X方向見通図（投入間隔: $30 \mathrm{~m}$ ）

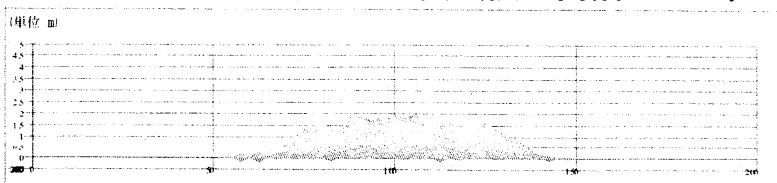

図-11(4) $Y$ 方向見通図（投入間隔 : $30 \mathrm{~m}$ ） 


\section{4. 結論}

本研究の結論を以下に示す.

1) 水理模型実験における中央部の堆積形状は, 投入 水深が $7 \mathrm{~m}, 10 \mathrm{~m}$ では 2 次元モデルである三菱モ デルとほぼ・致し，投入水深 $15 \mathrm{~m}, 20 \mathrm{~m}$ では仮想 3 次元モデルである造成 I 工区モデルとほぼ・致 する.

2) 本研究で構築した 3 次元堆積形状データベースを 用いることで土量, 水深, 開閉時間をパラメータ とした任意の堆積形状を予测することが可能であ る.

3) 本計算手法は, 堆積形状の重ね合わせについても 適用可能である.

4) 3 次元堆積形状データベースを更新することで, 更に精度を向上させることが可能である．また， 本研究で使用したパラメー夕（土量, 投入水深,
開閉時間）の他にも流れ（潮流）や，投入する土 砂の物性値等を考慮することでより現地に即した データベースを構築することが可能である.

謝辞 : 本吥究の作成に当たり御指導および御協力し て頂いた関西国際空港株式会社, 五洋建設技術䂺究 所に感謝致します。

\section{参考文献}

1) 武藤, 吉去, 石田: 大規模埋话用底開バージによる土砂 投下の吥究，三菱重丁技報，Vol. 11 No. 1, pp. 92-104, 1974-1.

2) 関西国際空港株式会社 建設事務局: 関西国際空港 空 港島造成丁。事（その 1） T.事報告書，p. 155， 1996-8. 